\author{
ANDRZEJ DERDZIUK OFMCap \\ Sekcja Teologii Moralnej KUL \\ e-mail: andrzej.derdziuk@kul.pl \\ DOI: https://doi.org/10.18290/rt.21683-9
}

\title{
SŁUGA LUDZKICH SUMIEŃ
}

Człowiek Bogu - Człowiek człowiekowi - Człowiek światu. Księga pamiatkowa dedykowana śp. ks. prof. dr. hab. Alojzemu Drożżowi (1950-2019), red. Wojciech Surmiak, Katowice: Księgarnia św. Jacka 2020, ss. 469.

Posługa myślenia, którą spełniają teologowie moraliści, polega na wskazywaniu światła Bożego, które nie tylko ukierunkowuje ludzkie życie, ale też dodaje mocy do urzeczywistniania rozpoznanego i przyjętego powołania. Oświetlając codzienność człowieka Bożym światłem ewangelicznej mądrości, teolog opisuje je w aspekcie dobra i zła i wskazuje kryteria do rozeznawania drogi prowadzącej do szczęścia i pokoju. Jest przez to sługa ludzkich sumień w odkrywaniu Bożej prawdy. Dlatego tak ważne jest, by w ramach twórczej obecności w Kościele teologowie mogli kierować się przykładem wytrawnych mistrzów, którzy swoim doświadczeniem potwierdzają i ubogacają nadzieję, że dobro może zostać rozpoznane i przyjęte. Z radością zatem trzeba przyjąć inicjatywę środowiska teologów z Wydziału Teologicznego Uniwersytetu Śląskiego w Katowicach wydania książki pamiątkowej poświęconej zmarłemu niedawno ks. prof. Alojzemu Drożdżowi.

Praca przygotowywana pod redakcją ks. Wojciecha Surmiaka nosi tytuł Człowiek Bogu - Człowiek człowiekowi - Człowiek światu i obejmuje trzy zasadnicze części poprzedzone okolicznościowymi wypowiedziami hierarchów Kościoła i innych osób. W strukturze książki przewidziano wprowadzenia do poszczególnych części, których autorem jest sam Jubilat. Publikacja bowiem była zamierzona jako prezent jubileuszowy na siedemdziesiąte urodziny ks. Profesora. Redaktor książki opracował i we wstępie zamieścił naukowy biogram ks. Drożdża oraz wskazał jego osiągnięcia naukowe w postaci wykazu opublikowanych tekstów i prezentacji wkładu w promocję nowych adeptów teologii.

Część pierwsza, zatytułowana Człowiek Bogu, zawiera osiem tekstów ofiarowanych przez przyjaciół i kolegów ks. Profesora, którzy skoncentrowali swoją refleksję naukową na zagadnieniach Dekalogu, powołania do świętości, sumienia oraz liturgii i duchowości, w tym szczególnie duchowości maryjnej. Autorzy pochodzą z różnych krajów, a teksty są zamieszczone w języku polskim, włoskim i niemieckim. Część ta wskazuje na wertykalny wymiar życia chrześcijańskiego, które to życie przez swoje odniesienie do Boga zyskuje sens i otrzymuje moc z wysoka. Zawarte w tej 
części artykuły potwierdzają głębokie przekonanie ks. Drożdża, że teologia moralna za swój przedmiot ma mówienie o Bogu, który powołuje człowieka do życia i go prowadzi.

W drugiej części publikacji znalazły się artykuły poświęcone zagadnieniu zatytułowanemu: Człowiek człowiekowi. Obejmują one dziewięć tekstów dotyczących prawa naturalnego, wolności, wychowania i upomnienia braterskiego. Znalazły się w nim też rozważania na temat obrony życia dzieci poczętych oraz ochrony danych osobowych w obiegu publicznym. Dwa ostatnie teksty w tej części omawiają realizację różnych rodzajów powołania chrześcijańskiego, w tym wypadku kapłanów i policjantów. Dobór autorów oraz różnorodność problematyki zapewniają ciekawą treść tej partii pracy.

Przedmiotem trzeciej części książki jest próba określenia miejsca człowieka w świecie w aspekcie wkładu w rozwój wartości ewangelicznych w ludzką społeczność. Chrześcijanie mogą się bowiem przyczyniać do przemiany świata przez refleksję etyczną i teologicznomoralną oraz przez prowadzenie i wspieranie dialogu społecznego. Istotne jest też działanie na rzecz ewangelizacji życia społeczno-ekonomicznego i rozwijanie edukacji ekologicznej przez promowanie zasad społecznej nauki Kościoła. Treści poruszane w tej części pracy są inspirujące dla teologii moralnej, która musi sobie odpowiedzieć na pytanie, w jakiej mierze adekwatnie reaguje na egzystencjalne wyzwania ludzi żyjących w epoce przełomu.

Specyfiką książek stanowiących zbiór tekstów ofiarowanych w ramach publikacji jubileuszowej jest różnorodność tematów i dobór autorów, którzy dzielą się z Jubilatem owocami swoich poszukiwań naukowych. Zarazem stanowi to ich bogactwo, bo nie ograniczając się do monograficznego zagadnienia zaprojektowanego przez redaktorów, autorzy podejmują istotne z ich punktu widzenia treści, które mogą otwierać czytelników na nowe spojrzenie na rzeczywistość. Omawiając bowiem różne zagadnienia z zakresu życia osobistego i społecznego, teologowie moraliści ukazują je w świetle Bożego światła Ewangelii i ukazuja konieczność kierowania się właściwymi kryteriami odróżniania dobra od zła.

Omawiana książka oferuje szerokie spektrum zagadnień i pozwala na zorientowanie się w zakresie przedsięwzięć naukowych ks. Alojzego Drożdża. Zarazem dostarcza wiele ciekawych rozważań z zakresu teologii moralnej. Trzeba stwierdzić, że publikowane artykuły nie są równej wartości i niektóre z nich znalazły się w książce jako wyciągnięte z szuflady. Na tym tle wyróżnia się swoją aktualnością i jakością tekst ks. Tadeusza Zadykowicza, który traktuje o istotnych zadaniach teologów moralistów w okresie zawirowań cywilizacyjnych. 